\title{
Eco-Friendly Management of Powdery Mildew (Erysiphe cruciferarum Opiz ex. Junell) Disease of Mustard [Brassica juncea (L.) Czern. \& Coss.] in North Saurashtra, India
}

\author{
K.K. Kanzaria ${ }^{*}$ and I.U. Dhruj ${ }^{2}$ \\ ${ }^{1}$ Dry Farming Research Station, Junagadh Agricultural University, \\ Jam-Khambhalia-361305. Gujarat, India \\ ${ }^{2}$ Office of the Director of Research, Junagadh Agricultural University, University Bhavan, \\ Junagadh - 362 001, Gujarat, India \\ *Corresponding author
}

A B S T R A C T

\begin{tabular}{|l|}
\hline K e y w or d s \\
Biopesticides, \\
Mustard, Neem leaf \\
extact, Powdery \\
mildew
\end{tabular}

\section{Introduction}

The oilseed crops, especially Brassica spp., play a pivotal role in the agricultural economy of India. It is the most important cultivated crop in India next to groundnut under a wide range of agroclimatic conditions. Rapeseed and mustard are considered to be of high economic importance in national and international trade with significant implications as they yield the most important edible oil ranging from 30-48 per cent which is used as the main cooking medium in North India.

The mustard crop is affected by various biotic and abiotic stresses causing considerable yield losses. Among biotic stresses, the damage caused by plant diseases is one of the major constraints. Powdery mildew caused by 
Erysiphe cruciferarum Opiz. Ex. Junell. is becoming widespread disease in most mustard growing areas of India including Gujarat. Erysiphe spp. can infect any above ground plant part and can cause heavy yield losses by reducing plant growth and consequently, the quantity and quality of seeds. Saharan and Sheoran (1985) observed that damage to mustard crop may be severe at the rate of 17.5 per cent when disease appears in early stage of plant growth. The yield losses were to the tune of 45 per cent at more than 90 per cent severity of powdery mildew. The yield loss due to this disease in mustard was estimated as 16.97 per cent in Gujarat (Dangeet al., 2002).

In recent years, an increasing consciousness about environmental pollution due to pesticides and development of fungicide resistant strains of plant pathogens has challenged to search for eco-friendly tools for disease management (Meena et al., 2011). However, limited effort was made to use plant extracts as 'eco-friendly' components for effective management of oilseed Brassica diseases. Keeping in view, an experiment was conducted to evaluate the relative efficacy of different biopesticides against powdery mildew disease caused by E. cruciferarum in mustard under field conditions.

\section{Materials and Methods}

A field experiment on powdery mildew disease of mustard was conducted during three consecutive rabi season of 2007-08 to 200910 at Dry Farming Research Station, Junagadh Agricultural University, Jam-Khambhalia, Gujarat, India where natural occurrence of powdery mildew disease in mustard was one of the major constraints in low yield of crop. Looking to its regular incidence in mustard, an experiment was arranged with biopesticidal management strategies of powdery mildew disease under natural condition. For that the experiment was layout in randomized block design in quadruplicates using mustard variety GM-2 @ $3.5 \mathrm{~kg} / \mathrm{ha}$ with gross plot size of 6.0 x $2.7 \mathrm{~m}$ at $45 \times 15 \mathrm{~cm}$ spacing. General agronomic practices were followed as and when required. The biopesticidal treatment comprising three neem base preparations viz., Neem seed kernel extract 2\%, Neem leaf extract $2 \%$ and Azadirachtin $0.15 \%$ W/W (Neemazal) $0.5 \%$ and Wettable sulphur $80 \%$ WP $0.2 \%$. The first spray of these products against powdery mildew of mustard was started on initiation of natural build-up of disease. Remaining application of spray were given at 12 days intervals. Simultaneously two control was also maintained, with water spray and without any spray.

Observations on powdery mildew intensity was recorded at seven days after last spray by selecting ten plants randomly from each plot using 0-12 scale (Solanki, 1995). Further the PDI was calculated with the above scales using the formula given by Wheeler (1969).

PDI $=($ Sum of total rating $/$ Total plants observed) $\mathrm{x}$ (100 / Maximum disease rating)

Seed yield of net plot area $4.0 \times 1.8 \mathrm{~m}$ was recorded after harvest of the crop. Finally, yield in $\mathrm{kg}$ per ha was worked out by multiplying yield of net plot area with multiple factor.

The percentage disease control and the percentage deviation in yield were calculated with the help of the following formula (Mathur et al., 1971).

P.D.I. in check - P.D.I. in treatment Disease control $(\%)=------------------$ x 100 P.D.I. in check

Yield in treatment - Yield in check Yield increase $(\%)=$--------------------- x 100 Yield in check

Loss was estimated on the basis of yield 
obtained in different treatments in terms of percentage according to formula given below (Gupta and Singh, 1981).

Yield of protected plot -

Yield of unprotected plot

Percent loss in yield $=$

Yield of protected plot

\section{Preparation of phytoextracts}

\section{Neem seed kernel extract}

Twenty grams of crushed neem seed kernels were soaked overnight in $500 \mathrm{ml}$ of water was squeezed through muslin cloth and then the volume made up to $1000 \mathrm{ml}$ to get two per cent concentration.

\section{Neem leaf extract}

Fresh and healthy neem leaves were collected and washed thoroughly with running tap water. These leaves were cut into small pieces and macerated in sterilized distilled water (1:1 w/v basis) in blender. Resulting crude extract was filtered through single layer of sterilized muslin cloth. Filtered extracts were considered as standard $(100 \%)$ solutions. Standard extracts were further diluted to desired concentrations $(2 \%)$ by adding required quantity of water for foliar spray.

\section{Estimation of oil and protein content}

Oil and protein content in the seeds were determined directly by using Near Infrared Spectroscope as described by Mandal et al., (2005). The mustard seed samples randomly drawn from each treatment were ground in mortar with pestle and screened through fine sieve. Thereafter about five $g$ of each ground seed samples were uniformly placed in a small ring cup $(3.8 \mathrm{~cm})$ for scanning on a Monocromator NIR reflectance spectroscopy for the measurement of oil and protein content in the treatment of different biopesticides due to powdery mildew disease of mustard in Food Testing Laboratory, Department of Biotechnology, Junagadh Agricultural University, Junagadh.

\section{0 seeds weight}

Counting and weighing of 1000-seeds randomly drawn from seed samples of each treatment was done by electronic digital balance. The three year data on effect of different treatments of biopesticides on PDI, seed yield, oil content, protein content and test weight were pooled and analyzed as per the standard statistical method.

\section{Results and Discussion}

North Saurashtra agroclimatic zone of Gujarat occupies uneven and erratic pattern of rainfall. After harvesting of kharif groundnut, bajra or sesame crop, sowing of mustard in rabi season is one of the less expensive and economical practice adopted by the farmers with limited irrigation facilities. In mustard, incidence of powdery mildew disease was one of the most serious problems for low yield which appears after flowering and needs proper management strategies for better yield. Different fungicides have been recommended to manage the disease, but use of natural plant products for the management of the disease and its efficacy under field condition still remain unknown for this region. Hence, present investigation was undertaken during three consecutive rabi season to evaluate the efficacy of different biofungicides against powdery mildew disease of mustard.

\section{Effect of biopesticides on percent disease intensity}

All neem base preparations and wettable sulphur were effective in reducing disease significantly as compared to control (Table 1). 
The minimum disease intensity 33.98 per cent (pooled) and maximum disease control 47.99 per cent was registered with the application of wettable sulphur $(0.2 \%)$. Wettable sulphur was found effective and exhibited minimum PDI of $35.80,34.35$ and 31.84 during the years 2007-08, 2008-09 and 2009-10 respectively.

In pooled analysis, the leaf extract of neem $2 \%$ recorded 38.35 PDI followed by neem seed kernel extract $2 \%$ and azadirachtin $0.5 \%$ with 44.53 and 50.80 PDI, respectively as compared to no spray control 86.65. The water spray control showed 83.33, 85.21 and 79.99 PDI as compared to no spray control 85.85, 88.97 and 85.01 PDI during three consecutive rabi seasons of 2007-08 to 2009-10 and were found at par only during 2007-08.

The per cent disease control ranged from 33.70 to 47.99. Maximum disease control of 47.99 per cent was observed in the treatment of wettable sulphur followed by neem leaf extract (44.20\%), neem seed kernel extract $(38.95 \%)$ and azadirachtin $(33.70 \%)$ as compared to no spray control.

\section{Effect of biopesticides on seed yield}

All biopesticidal treatments significantly increased the mustard yield ranging from 17.13 to 29.92 per cent as compared to no spray control (Table 2).

During the year 2007-08 and 2009-10 wettable sulphur $0.2 \%$ recorded significantly the highest mustard yield of 2111 and $2252 \mathrm{~kg} / \mathrm{ha}$, respectively, followed by neem leaf extract $2 \%$ (1987 and $2116 \mathrm{~kg} / \mathrm{ha}$ ), neem seed kernel extract 2\% (1967, 1901 and $2089 \mathrm{~kg} / \mathrm{ha})$ and azadirachtin0.5\% (1894 and $2060 \mathrm{~kg} / \mathrm{ha})$ as compared to no spray control (1652 and 1705 $\mathrm{kg} / \mathrm{ha}$ ).

In pooled result, significantly the highest mustard seed yield of $2154 \mathrm{~kg} / \mathrm{ha}$ was recorded in the treatment of wettable sulphur and was found to be equally good as neem leaf extract $2013 \mathrm{~kg} / \mathrm{ha}$. The next best treatment was neem seed kernel extract $(1986 \mathrm{~kg} / \mathrm{ha})$ which was at par with azadirachtin (1942 $\mathrm{kg} / \mathrm{ha}$ ) as compared to no spray control (1658 $\mathrm{kg} / \mathrm{ha}$ ). Decreased per cent disease intensity from 86.65 to 33.98 resulted in per cent increase in seed yield over no spray control in all the tested biopesticides with best being wettable sulphur $(29.92 \%)$ followed by neem leaf extract $(21.41 \%)$, neem seed kernel extract (19.78\%) and azadirachtin (17.13\%). The use of neem based biopesticides for the management of powdery mildew of various crops under field condition was reported earlier. The spraying of fresh neem leaf extract at two per cent or 0.2 per cent wettable sulphur were better for the control of powdery mildew of mustard in South Saurashtra (Gujarat) conditions (Anon., 1996). Laxmanrao (1998) reported that behda (Terminaliabelerica) leaf extract (5\%) was significantly superior against powdery mildew of mustard followed by neem leaf extract (5\%). Sindhan et al., (1999) reported that Neemadol (a neem product) and extracts of $A$. indica, Allium cepa, A. sativum and Zingiberofficinale were highly effective for powdery mildew of pea and were at par with Karathane in reducing disease intensity. Dinesh et al., (2011) revealed that at five per cent azadirachtin (1500 ppm, 1:10 dilution) was significantly superior. It was on par with NSKE and was followed by Lantana and turmeric leaf extracts in controlling sunflower powdery mildew. Chovatiya et al., (2012) evaluated different biopesticides against powdery mildew of fenugreek and reported that neem leaf extract $(5 \%)$ was the most effective in controlling the disease and also for higher seed production. They also reported neem seed kernel extract as the next best effective treatment. 
Rating scale with infection/phenotypic class (Solanki, 1995)

\begin{tabular}{|c|c|}
\hline Rating Scale & Infection/phenotypic class \\
\hline 0 & Healthy (i.e. no disease symptoms on the plant) \\
\hline I & Few whitish specks ( 1 to 5 ) on leaf \\
\hline II & Up to 25 per cent leaf area covered with whitish specks \\
\hline III & $>25$ to 50 per cent leaf area covered with whitish fungal growth \\
\hline IV & $\begin{array}{l}\text { More than } 50 \text { per cent area of leaf covered with whitish fungal growth and few } \\
\text { whitish specks on stem }\end{array}$ \\
\hline $\mathrm{V}$ & $\begin{array}{l}\text { More than } 50 \text { per cent area of leaf and up to } 25 \text { per cent area on stem covered with } \\
\text { whitish growth }\end{array}$ \\
\hline VI & More than 50 per cent area of leaf and stem covered with whitish growth \\
\hline VII & $\begin{array}{l}\text { More than } 50 \text { per cent area of leaf and stem covered by whitish growth with few } \\
\text { whitish specks on branch(es) }\end{array}$ \\
\hline VIII & $\begin{array}{l}\text { More than } 50 \text { per cent area of leaf, stem and up to } 25 \text { per cent area of branch(es) } \\
\text { covered with whitish growth }\end{array}$ \\
\hline IX & $\begin{array}{l}\text { More than } 50 \text { per cent area of leaf, stem and branch(es) covered with whitish } \\
\text { fungal growth }\end{array}$ \\
\hline$X$ & $\begin{array}{l}\text { More than } 50 \text { per cent area of leaf, stem and branch(es) covered with whitish } \\
\text { fungal growth with few whitish specks on siliquae }\end{array}$ \\
\hline XI & $\begin{array}{l}\text { More than } 50 \text { per cent area of leaf, stem, branch(es) covered with whitish fungal } \\
\text { growth and up to } 25 \text { per cent area of siliquae covered with whitish growth }\end{array}$ \\
\hline XII & $\begin{array}{l}\text { More than } 50 \text { per cent area of leaf, stem, branch(es) and siliquae covered with } \\
\text { whitish growth (i.e. entire plant covered with whitish fungal growth) }\end{array}$ \\
\hline
\end{tabular}

Table.1 Per cent disease intensity of powdery mildew influenced by biopesticides in mustard

\begin{tabular}{|c|c|c|c|c|c|c|}
\hline \multirow{2}{*}{$\begin{array}{l}\text { Sr. } \\
\text { No. }\end{array}$} & \multirow[t]{2}{*}{ Treatment } & \multicolumn{3}{|c|}{ Disease intensity (\%) } & \multirow{2}{*}{$\begin{array}{c}\text { Pooled } \\
\text { mean }\end{array}$} & \multirow{2}{*}{$\begin{array}{c}\text { Disease } \\
\text { control }(\%)\end{array}$} \\
\hline & & 2007-08 & 2008-09 & 2009-10 & & \\
\hline 1. & $\begin{array}{l}\text { Neem seed kernel } \\
\text { extract } 2 \%\end{array}$ & $\begin{array}{c}42.09 \\
(44.94)\end{array}$ & $\begin{array}{c}41.63 \\
(44.13)\end{array}$ & $\begin{array}{c}41.87 \\
(44.55)\end{array}$ & $\begin{array}{c}41.86 \\
(44.53)\end{array}$ & 38.95 \\
\hline 2. & $\begin{array}{l}\text { Neem leaf } \\
\text { extract 2\% }\end{array}$ & $\begin{array}{c}39.45 \\
(40.37)\end{array}$ & $\begin{array}{c}38.85 \\
(39.35)\end{array}$ & $\begin{array}{c}36.50 \\
(35.39)\end{array}$ & $\begin{array}{c}38.26 \\
(38.35)\end{array}$ & 44.20 \\
\hline 3. & $\begin{array}{l}\text { Azadirachtin } \\
0.5 \%\end{array}$ & $\begin{array}{c}47.38 \\
(54.15)\end{array}$ & $\begin{array}{c}44.62 \\
(49.34)\end{array}$ & $\begin{array}{c}44.39 \\
(48.94)\end{array}$ & $\begin{array}{l}45.46 \\
(50.80)\end{array}$ & 33.70 \\
\hline 4. & $\begin{array}{l}\text { Wettable } \\
\text { Sulphur } 0.2 \%\end{array}$ & $\begin{array}{c}36.75 \\
(35.80)\end{array}$ & $\begin{array}{c}35.88 \\
(34.35)\end{array}$ & $\begin{array}{c}34.35 \\
(31.84)\end{array}$ & $\begin{array}{c}35.66 \\
(33.98)\end{array}$ & 47.99 \\
\hline 5. & $\begin{array}{l}\text { Control } \\
\text { (Water spray) }\end{array}$ & $\begin{array}{c}65.90 \\
(83.33)\end{array}$ & $\begin{array}{c}67.38 \\
(85.21)\end{array}$ & $\begin{array}{c}63.43 \\
(79.99)\end{array}$ & $\begin{array}{c}65.57 \\
(82.90)\end{array}$ & 4.38 \\
\hline 6. & $\begin{array}{l}\text { Control } \\
\text { (No spray) }\end{array}$ & $\begin{array}{c}67.90 \\
(85.85)\end{array}$ & $\begin{array}{c}70.60 \\
(88.97)\end{array}$ & $\begin{array}{c}67.22 \\
(85.01)\end{array}$ & $\begin{array}{c}68.57 \\
(86.65)\end{array}$ & - \\
\hline & S.Em.土 & 0.83 & 0.69 & 0.80 & 0.66 & \\
\hline & C.D. at $5 \%$ & 2.51 & 2.08 & 2.42 & 2.09 & \\
\hline & C.V.\% & 3.34 & 2.77 & 3.34 & 3.16 & \\
\hline
\end{tabular}

*Data given in parenthesis are retransformed values. 
Table.2 Biopesticidal control of powdery mildew of mustard with their impact on seed yield

\begin{tabular}{|c|c|c|c|c|c|c|}
\hline \multirow[t]{2}{*}{ Sr. No. } & \multirow[t]{2}{*}{ Treatment } & \multicolumn{3}{|c|}{ Seed yield (kg/ha) } & \multirow{2}{*}{$\begin{array}{c}\text { Pooled } \\
\text { mean }\end{array}$} & \multirow{2}{*}{$\begin{array}{c}\text { Seed yield } \\
\text { increase }(\%)\end{array}$} \\
\hline & & 2007-08 & 2008-09 & 2009-10 & & \\
\hline 1. & $\begin{array}{l}\text { Neem seed kernel } \\
\text { extract } 2 \%\end{array}$ & 1967 & 1901 & 2089 & 1986 & 19.78 \\
\hline 2. & $\begin{array}{l}\text { Neem leaf } \\
\text { extract } 2 \%\end{array}$ & 1987 & 1935 & 2116 & 2013 & 21.41 \\
\hline 3. & $\begin{array}{l}\text { Azadirachtin } \\
0.5 \%\end{array}$ & 1894 & 1871 & 2060 & 1942 & 17.13 \\
\hline 4. & $\begin{array}{l}\text { Wettable sulphur } \\
0.2 \%\end{array}$ & 2111 & 2100 & 2252 & 2154 & 29.92 \\
\hline 5. & $\begin{array}{l}\text { Control } \\
\text { (Water spray) }\end{array}$ & 1710 & 1691 & 1800 & 1734 & 4.58 \\
\hline \multirow[t]{4}{*}{6.} & $\begin{array}{l}\text { Control } \\
\text { (No spray) }\end{array}$ & 1652 & 1616 & 1705 & 1658 & - \\
\hline & S. Em. \pm & 94.64 & 106.27 & 120.50 & 56.57 & \\
\hline & C.D. at $5 \%$ & 285.22 & NS & 363.16 & 160.37 & \\
\hline & C.V.\% & 10.03 & 11.47 & 12.03 & 11.25 & \\
\hline
\end{tabular}

Table.3 Effect of biopesticides applied for control of powdery mildew on oil content of mustard

\begin{tabular}{|c|c|c|c|c|c|c|}
\hline \multirow{2}{*}{$\begin{array}{l}\text { Sr. } \\
\text { No. }\end{array}$} & \multirow[t]{2}{*}{ Treatment } & \multicolumn{3}{|c|}{ Oil content (\%) } & \multirow{2}{*}{$\begin{array}{l}\text { Pooled } \\
\text { mean }\end{array}$} & \multirow{2}{*}{$\begin{array}{l}\text { Oil content } \\
\text { increase }(\%)\end{array}$} \\
\hline & & 2007-08 & 2008-09 & 2009-10 & & \\
\hline 1. & $\begin{array}{l}\text { Neem seed kernel } \\
\text { extract } 2 \%\end{array}$ & 34.49 & 32.38 & 33.65 & 33.50 & 8.45 \\
\hline 2. & $\begin{array}{l}\text { Neem leaf } \\
\text { extract } 2 \%\end{array}$ & 35.28 & 32.50 & 34.12 & 33.97 & 9.97 \\
\hline 3. & $\begin{array}{l}\text { Azadirachtin } \\
0.5 \%\end{array}$ & 34.47 & 31.71 & 32.63 & 32.94 & 6.64 \\
\hline 4. & $\begin{array}{l}\text { Wettable } \\
\text { Sulphur 0.2\% }\end{array}$ & 35.40 & 32.59 & 34.36 & 34.12 & 10.46 \\
\hline 5. & $\begin{array}{l}\text { Control } \\
\text { (Water spray) }\end{array}$ & 33.37 & 30.87 & 30.93 & 31.72 & 2.69 \\
\hline 6. & $\begin{array}{l}\text { Control } \\
\text { (No spray) }\end{array}$ & 32.12 & 29.93 & 30.63 & 30.89 & - \\
\hline & S.Em.t. & 0.72 & 0.55 & 0.67 & 0.35 & \\
\hline & C.D. at $5 \%$ & 2.17 & 1.66 & 2.01 & 1.00 & \\
\hline & C.V.\% & 4.22 & 3.49 & 4.09 & 3.96 & \\
\hline
\end{tabular}


Table.4 Effect of biopesticides applied for control of powdery mildew on protein content of mustard

\begin{tabular}{|c|c|c|c|c|c|c|}
\hline \multirow[t]{2}{*}{ Sr. No. } & \multirow[t]{2}{*}{ Treatment } & \multicolumn{3}{|c|}{ Protein content (\%) } & \multirow{2}{*}{$\begin{array}{l}\text { Pooled } \\
\text { mean }\end{array}$} & \multirow{2}{*}{$\begin{array}{c}\text { Protein } \\
\text { content } \\
\text { increase } \\
(\%)\end{array}$} \\
\hline & & 2007-08 & 2008-09 & 2009-10 & & \\
\hline 1. & $\begin{array}{l}\text { Neem seed kernel } \\
\text { extract } 2 \%\end{array}$ & 15.98 & 17.22 & 16.44 & 16.54 & 14.31 \\
\hline 2. & $\begin{array}{l}\text { Neem leaf } \\
\text { extract } 2 \%\end{array}$ & 16.35 & 17.26 & 16.45 & 16.69 & 15.34 \\
\hline 3. & $\begin{array}{l}\text { Azadirachtin } \\
0.5 \%\end{array}$ & 15.96 & 16.90 & 16.16 & 16.34 & 12.92 \\
\hline 4. & $\begin{array}{l}\text { Wettable sulphur } \\
0.2 \%\end{array}$ & 16.54 & 18.08 & 16.72 & 17.11 & 18.24 \\
\hline 5. & $\begin{array}{l}\text { Control } \\
\text { (Water spray) }\end{array}$ & 15.11 & 16.10 & 14.54 & 15.25 & 5.39 \\
\hline \multirow[t]{4}{*}{6.} & $\begin{array}{l}\text { Check } \\
\text { (No spray) }\end{array}$ & 14.63 & 15.66 & 13.10 & 14.47 & - \\
\hline & S.Em. \pm & 0.31 & 0.36 & 0.38 & 0.21 & \\
\hline & C.D. at $5 \%$ & 0.92 & 1.10 & 1.16 & 0.60 & \\
\hline & C.V.\% & 3.88 & 4.32 & 4.93 & 4.39 & \\
\hline
\end{tabular}

Table.5 Effect of biopesticides applied for control of powdery mildew on 1000 seeds weight $(\mathrm{g})$ of mustard

\begin{tabular}{|c|c|c|c|c|c|c|}
\hline \multirow{2}{*}{$\begin{array}{l}\text { Sr. } \\
\text { No. }\end{array}$} & \multirow{2}{*}{ Treatment } & \multicolumn{3}{|c|}{ 1000-seeds weight $(\mathrm{g})$} & \multirow{2}{*}{$\begin{array}{c}\text { Pooled } \\
\text { mean }\end{array}$} & \multirow{2}{*}{$\begin{array}{c}\text { Increase in } \\
\text { test weight } \\
(\%)\end{array}$} \\
\hline & & 2007-08 & 2008-09 & 2009-10 & & \\
\hline 1. & $\begin{array}{l}\text { Neem seed kernel } \\
\text { extract } 2 \%\end{array}$ & 5.30 & 5.35 & 5.24 & 5.29 & 21.61 \\
\hline 2. & $\begin{array}{l}\text { Neem leaf } \\
\text { extract } 2 \%\end{array}$ & 5.45 & 5.42 & 5.27 & 5.38 & 23.68 \\
\hline 3. & $\begin{array}{l}\text { Azadirachtin } \\
0.5 \%\end{array}$ & 5.16 & 5.28 & 5.23 & 5.23 & 20.23 \\
\hline 4. & $\begin{array}{l}\text { Wettable sulphur } \\
0.2 \%\end{array}$ & 5.67 & 5.66 & 5.42 & 5.58 & 28.28 \\
\hline 5. & $\begin{array}{l}\text { Control } \\
\text { (Water spray) }\end{array}$ & 4.64 & 4.46 & 4.34 & 4.48 & 2.99 \\
\hline 6. & $\begin{array}{l}\text { Check } \\
\text { (No spray) }\end{array}$ & 4.51 & 4.33 & 4.22 & 4.35 & - \\
\hline & S.Em. \pm & 0.07 & 0.07 & 0.07 & 0.04 & \\
\hline & C.D. at $5 \%$ & 0.20 & 0.21 & 0.21 & 0.12 & \\
\hline & C.V.\% & 2.60 & 2.73 & 2.85 & 2.72 & \\
\hline
\end{tabular}


In contradiction to the present finding Patel and Patel (2008) used neem (A. indica), eucalyptus (Eucalyptus globulens), karan (Neriumindicum), karanj (Pongamiapinnata) and bulb extract of onion ( $A$. cepa), each at five per cent, against powdery mildew of mustard. They found none of the phytoextracts helped in reducing the disease significantly and all the phytoextracts failed to increase the yield significantly over the control. It could be possible that the fungal isolate used in that study was not sensitive to these extracts.

\section{Effect of biopesticides on oil content (\%)}

Among different treatments tried, wettable sulphur recorded significantly high oil content of 34.12 per cent followed by neem leaf extract $(33.97 \%)$ and neem seed kernel extract $(33.50 \%)$ treatments (Table 3). Azadirachtain spray was least effective in improving oil content $(32.94 \%)$ as compared to no spray control $(30.89 \%)$ in pooled analysis.

Wettable sulphur treated plants showed the highest amount of oil content 35.40, 32.59 and 34.36 per cent and were at par with neem leaf extract $(35.28,32.50$ and $34.12 \%)$ followed by neem seed kernel extract (34.49, 32.38 and $33.65 \%$ ) and azadirachtin (34.47, 31.71 and $32.63 \%$ ) during the years 2007-08, 2008-09 and 2009-10, respectively, as compared to no spraycontrol $(32.12,29.93$ and 30.63 per cent for the corresponding years). All the treatments were effective and recorded 6.64 to 10.46 per cent increase in oil content over control. The maximum per cent increase in oil content was recorded in the treatment of wettable sulphur (10.46\%) followed by neem leaf extract $(9.97 \%)$, neem seed kernel extract $(8.45 \%)$ and azadirachtin $(6.64 \%)$ over no spray control.

The present findings are in accordance with the findings of Degenhardt et al., (1974).
They noticed losses in oil content up to 4.8 per cent due to leaf blight disease in mustard. Higher losses (14.6-36 \%) were recorded for the same disease in India by Ansari et al., 1988.

\section{Effect of biopesticides on protein content (\%)}

Among different biopesticides tried, the lowest protein content of 16.34 was observed in azadirachtin treated plants (Table 4), whereas, foliar spray with wettable sulphur was significantly superior over rest of the treatments and recorded maximum protein content of 17.11 per cent followed by neem leaf extract $(16.69 \%)$ and neem seed kernel extract $(16.54 \%)$ when the pooled analysis was done.

In individual years, significantly the higher protein content was recorded in the treatment of wettable sulphur(16.54 and18.08\%) followed by neem leaf extract (16.35 and $17.26 \%)$ and neem seed kernel extract (15.98 and 17.22\%) during 2007-08 and 2008-09 as compared to no spray control and were also remained statistically at par. Whereas, in the year 2009-10, all treatments significantly increased protein content in comparison to both the checks. All the treatments were effective and recorded 12.92 to 18.24 per cent increase in protein content over control. The maximum per cent increase in protein content was recorded in the treatment of wettable sulphur (18.24\%) followed by neem leaf extract $(15.34 \%)$, neem seed kernel extract $(14.31 \%)$ and azadirachtin $(12.92 \%)$ over no spray control.

More or less similar findings were also reported by Mert-Turk et al., (2008). They concluded that nitrogen fertilization increased the protein, but lowered the oil content of the seeds. Fungicidal treatments significantly increased oil contents in all varieties tested, however reduced protein levels in fertilized and non-fertilized plots. 


\section{Effect of biopesticides on 1000 seeds weight} (g)

All biofungicidal treatments significantly increased the 1000-seeds weight (Table 5). During the year 2007-08 significantly the maximum 1000-seeds weight $5.67 \mathrm{~g}$ was recorded in the treatment of wettable sulphur. The next best treatment was neem leaf extract (5.45 g) which was at par with neem seed kernel extract (5.30 g). Minimum 1000-seeds weight was recorded in azadirachtin $(5.16 \mathrm{~g})$ as compared to no spray control (4.51 g) while, during the year 2008-09, wettable sulphur recorded maximum 1000-seeds weight of $5.66 \mathrm{~g}$. The other treatments viz, neem leaf extract, neem seed kernel extract and azadirachtin were equally good and reported 5.42, 5.35 and $5.28 \mathrm{~g} 1000$-seeds weight respectively, as compared to no spray control (4.33 g). During the year 2009-10, all the tested biopesticides were on par. Wettable sulphur recorded $5.42 \mathrm{~g}$ seed weight followed by neem leaf extract $(5.27 \mathrm{~g})$, neem seed kernel extract (5.24 g) and azadirachtin (5.23 g) as compared to no spray control (4.22 g).

Pooled analysis showed significantly the maximum 1000-seeds weight of $5.58 \mathrm{~g}$ in the treatment of wettable sulphur. The next best treatment was neem leaf extract with $5.38 \mathrm{~g}$ of 1000 -seeds weight and was at par with neem seed kernel extract treatment that recorded $5.29 \mathrm{~g}$ of 1000 seeds weight. The minimum test weight of $5.23 \mathrm{~g}$ was recorded in the treatment of azadirachtin as compared to no spray control $4.35 \mathrm{~g}$. The maximum per cent increase in 1000-seeds weight was recorded in the treatment of wettable sulphur $(28.28 \%)$ followed by neem leaf extract (23.68\%), neem seed kernel extract $(21.61 \%)$ and azadirachtin $(20.23 \%)$ over no spray control. Patel (2006) also concluded that foliar sprays of fungicides for the control of powdery mildew of mustard gave test weight of 1000seeds in the range of 5.66-5.82 $\mathrm{g}$ as compared to $5.39 \mathrm{~g}$ in control.

In order to find out an effective and ecofriendly approach in controlling the powdery mildew disease of mustard in vivo, three neem base preparations along with wettable sulphur were tried. Among them, neem leaf extract $2 \%$ prove the most effective biopesticide and recorded 38.35 PDI followed by neem seed kernel extract $2 \%$ with 44.53 PDI and azadirachtin $0.5 \%$ with 50.80 PDI in three year pooled results as against 86.65 PDI recorded in untreated control.

Maximum disease control of 44.20 per cent was found in the treatment of neem leaf extract followed by neem seed kernel extract $(38.95 \%)$ and azadirachtin $(33.70 \%)$ with 2013, 1986 and $1942 \mathrm{~kg} / \mathrm{ha}$ of yield, respectively as compared to no spray control. Per cent increase in seed yield was also recorded higher in the treatment of neem leaf extract $(21.41 \%)$ followed by neem seed kernel extract $(19.78 \%)$ and azadirachtin $(17.13 \%)$.

The maximum oil, protein and test weight $(33.97 \%, 16.69 \%$ and $5.38 \mathrm{~g})$ was recorded in the treatment of neem leaf extract followed by neem seed kernel extract $(33.50 \%, 16.54 \%$ and 5.29 g.) and azadirachtain (32.94\%, $16.34 \%$ and $5.23 \mathrm{~g}$ ) as compared to no spray control $(30.89 \%, 14.47 \%$ and $4.35 \mathrm{~g})$. The maximum per cent increase in oil, protein and test weight $(9.97 \%, 15.34 \%$ and $23.68 \%)$ was recorded in the treatment of neem leaf extract followed by neem seed kernel extract $(8.45 \%$, $14.31 \%$ and $21.61 \%$ ) and azadirachtin $(6.64 \%, 12.92 \%$ and $20.23 \%)$.

However, wettable sulphur $0.2 \%$ was the best among all treatments tried and gave minimum 33.98 PDI with 47.99 per cent disease control, maximum seed yield of $2154 \mathrm{~kg} / \mathrm{ha}$ with 29.92 per cent increase in seed yield, maximum oil content $34.12 \%$ with 10.46 per 
cent increase in oil, maximum protein content $17.11 \%$ with 18.24 per cent increase in protein and 1000 seed weight of $5.58 \mathrm{~g}$ with 28.28 per cent increase in test weight as against no spray control. Wettable sulphur $0.2 \%$ was superior to all but, among different neem base preparations tested neem leaf extract $2 \%$ was next best and closest to wettable sulphur in limiting the powdery mildew incidence in field condition which was also found to increase in seed yield, oil content, protein content and 1000 seed weight. In view to avoid hazardous effect due to constant use of fungitoxic chemicals for management of powdery mildew disease of mustard, neem base preparation particularly neem leaf extract at 2\% was safe and found effective under field condition.

\section{References}

Anonymous, (1996). AGRESCO Report. Main Oilseeds Research Station, Gujarat Agricultural University, Junagadh.

Ansari, N. A., Khan, M. W. and Muheet, A. (1988). Effect of Alternaria blight on oil content of rape-seed and mustard. Curr. Sci. 57(18): 1023-1024.

Chovatiya, A. J., Dhruj, I. U., Varsani, V. R., Undhad, S. V. and Talaviya, J. R. (2012). Evaluation of different fungicides and biopesticides against powdery mildew of fenugreek (Trigonella foenumgraecum L.) Abstract published in $3^{\text {rd }}$ Global Conference - Plant Pathology for Food Security, organized by Indian Society of Mycology and Plant Pathology and Maharana Pratap University of Agriculture and Technology, Udaipur on 10-13, January, 2012 p. 164.

Dange, S. R. S., Patel, R. L., Patel, S. I. and Patel, K. K. (2002). Assessment of losses in yield due to powdery mildew disease in mustard under North Gujarat conditions. J. Mycol. Pl. Pathol. 32(2): 249-250.

Degenhardt, K. J., Skoropad, W. P. and Kondra, Z. P. (1974). Effect of alternaria blackspot on yield, oil content and protein content of rapeseed. Can. J. Plant Sci. 54: 795-799.

Dinesh, B. M., Kulkarni, S., Harlapur, S. I. and Benagi, V. I. (2011). Management of sunflower powdery mildew (Erysiphe cichoracearum). J. Mycol. Pl. Pathol. 41(1): 49-52.

Gupta, R. P. and Singh, A. (1981). Field evaluation of tolerance in wheat to brown rust. Indian Phytopath. 34(3): 300-303.

Laxmanrao, K. K. (1998). Studies of powdery mildew of mustard (Brassica juncea (L.) Coss). Thesis Abstracts. 24(1):7980.

Mandal, S., Singh, R., Bist, K. S. and Singh, M. (2005). Analysis of rapeseedmustard seeds by near infrared reflectance spectroscopy for total oil content. J. Oilseeds Res. 22(2): 279288.

Mathur, R. L., Singh, G. and Gupta, R. B. L. (1971). Field evaluation of fungicides for the control of powdery mildew of pea. Indian J. Mycol. Pl. Pathol. 1(2): 95-98.

Meena, P. D., Awasthi, R. P., Godika, S., Gupta, J. C., Kumar, A., Sandhu, P. S., Sharma, P., Rai, P. K., Singh, Y. P., Rathi, A. S., Prasad, R., Rai, D. and Kolte, S. J. (2011). Eco-friendly approaches managing major diseases of Indian Mustard. World Appl. Sci. J. 12(8): 1192-1195.

Mert-Turk, F., Gul, M. K. and Egesel, C. O. (2008). Nitrogen and fungicide applications against Erysiphe cruciferarum affect quality components of oilseed rape. Mycopathologia 165(1): 27-35.

Patel, J. S. (2006). Powdery mildew of 
mustard [Brassica juncea (Linn.) Czern and Coss] and its management. M.Sc.(Agri.) Thesis submitted to Anand Agricultural University, Anand. pp.54.

Patel, J. S. and Patel, S. J. (2008). Influence of foliar sprays of fungicides, phytoextracts and bioagent on powdery mildew and yield of mustard. Karnataka J. Agric. Sci. 21(3): 462-463. Saharan, G. S. and Sheoran, B. S. (1985). Assessment of losses in yield of mustard due to powdery mildew diseases. Cruciferae News Letter10: $112-113$.
Sindhan, G. S., Hooda, I. and Parashar, R. D. (1999). Evaluation of plant extracts for the control of powdery mildew of pea. J. Mycol. Pl. Pathol. 29(2): 257-258.

Solanki, V. A. (1995). Powdery mildew (Erysiphe cruciferarum Opiz ex Junell) of Indian mustard, its relationship with weather and management. Ph.D. Thesis submitted to the Gujarat Agricultural University, Anand. pp.120.

Wheeler, B. E. J. (1969). An Introduction to Plant Disease. John Wiley and Sons Ltd., London, Pp. 301.

\section{How to cite this article:}

Kanzaria, K.K. and Dhruj, I.U. 2018. Eco-Friendly Management of Powdery Mildew (Erysiphe cruciferarum Opiz ex. Junell) Disease of Mustard [Brassica juncea (L.) Czern. \& Coss.] in North Saurashtra, India. Int.J.Curr.Microbiol.App.Sci. 7(02): 738-748. doi: https://doi.org/10.20546/ijcmas.2018.702.093 